\title{
Sprawozdanie z Seminarium Naukowego Zakladu Historii Wychowania WSE UAM w Obrzycku (15-16.06.2016), pt. Źródła materialne w badaniach historyczno-pedagogicznych
}

DOI: $10.14746 /$ BHW.2016.35.13

W dniach 15-16 czerwca 2016 r. odbyło się, zgodnie z tradycją, coroczne Seminarium Naukowe, organizowane przez Zakład Historii Wychowania Wydziału Studiów Edukacyjnych Uniwersytetu im. Adama Mickiewicza w Poznaniu. Tym razem hasłem przewodnim były „Źródła materialne w badaniach historyczno-pedagogicznych”, co doskonale wpisało się w kilkuletni cykl, dotyczący warsztatu badawczego współczesnych historyków wychowania.

Obrady plenarne zainaugurowała dr Katarzyna Kabacińska-Łuczak interesującym referatem na temat biografii rzeczy, z uwzględnieniem źródeł pojęcia, głównych przedstawicieli i roli prof. Ewy Domańskiej (która zresztą kilka lat wcześniej gościła na Seminarium $\mathrm{z}$ referatem metodologicznym) w rozwoju odpowiedniej metodologii w Polsce. W części zasadniczej przedstawione zostały podstawowe idee związane $\mathrm{z}$ historią rzeczy, zagadnienie krótkiego lub długiego czasu trwania w ich przypadku oraz główne problemy metodologiczne. Po referacie odbyła się dyskusja, przede wszystkim dotycząca funkcji omawianych przedmiotów (zabawki czy egzemplarze kolekcjonerskie).

W dalszej części dr Monika Nawrot-Borowska zdała relację z naukowego objazdu muzeów zabawek w Niemczech: Norymberga-Sonneberg, Coburg-Neustadt/Coburg-Arnstadt, przedstawiając bardzo bogaty zbiór fotografii, prezentujących zbiory muzealne i opatrując to bogatym komentarzem. Przedmiotowy objazd realizowany był w ramach projektu badawczego, dotyczącego zabaw i zabawek dziecięcych, którego kierownikiem jest prof. dr hab. Dorota Żołądź-Strzelczyk.

Inny charakter miał referat dra hab. Jacka Taraszkiewicza, który szczegółowo omówił materiały źródłowe z XVII i XVIII wieku, przechowywane w Archivo generale delle Scuole Roma, prezentując skany wybranych dokumentów i omawiając trudności metodyczne i organizacyjne, związane z pracą nad dawnymi rękopisami łacińskimi. Po krótkiej przerwie kawowej dr Mariusz Brodnicki przedstawił problematykę starodruków Gdańskiego Gimnazjum Akademickiego. Spotkanie zostało zakończone prezentacją książek pracowników Zakładu Historii Wychowania.

Pierwszy dzień obrad zakończył się spotkaniem integracyjnym poznańskiego oddziału Towarzystwa Historii Edukacji, Zespołu Historii Wychowania przy KNP PAN i zaproszonych gości. Drugi dzień spotkania został zdominowany przez wspólne rozmowy i zwiedzanie części pałacowej zespołu uniwersyteckiego w Obrzycku.

Michat Nowicki 